\title{
Essential oil content, chamazulene content and antioxidative properties of Achillea millefolium agg. extracts from Slovenia
}

\author{
Boris TURK ${ }^{1,2}$, Dea BARIČEVIČ ${ }^{1}$, Franc BATIČ ${ }^{1}$
}

Essential oil content, chamazulene content and antioxidative properties of Achillea millefolium agg. extracts from Slovenia

Abstract: The study aimed to clarify some biochemical properties, important for the phytopharmaceutical use of yarrow from the A. millefolium agg.. The study comprised 41 populations from Slovenia. The most abundant taxa were included: Achillea millefolium L., A. roseoalba Ehrend., A. collina (Wirtg.) Becker ex Rchb., A. distans Waldst. \& Kit. ex Willd., A. pannonica Scheele, A. pratensis Saukel \& R.Länger and A. nobilis L. Assessment of essential oil content with the steam distillation method showed no significant difference between taxa. Essential oil content was the lowest in A. collina $\left(6.50 \mathrm{ml} \mathrm{kg}^{-1}\right.$ of dry matter), followed by A. pannonica $\left(7.75 \mathrm{ml} \mathrm{kg}^{-1}\right)$, A. distans $\left(8.50 \mathrm{ml} \mathrm{kg}^{-1}\right)$, A. nobilis $\left(9.40 \mathrm{ml} \mathrm{kg}^{-1}\right)$, A. pratensis $(9.65 \mathrm{ml} \mathrm{kg}$ $\left.{ }^{1}\right)$, A. nobilis $\times$ A. millefolium $\left(12.25 \mathrm{ml} \mathrm{kg}^{-1}\right)$, A. roseoalba (12.75 ml kg-1) and A. millefolium $\left(13.50 \mathrm{ml} \mathrm{kg} \mathrm{kg}^{-1}\right)$. The content of azulenes was determined by photometrical measurement of chamazulene in essential oil extracts. Chamazulene was only present in the diploid taxon and one tetraploid taxon, i.e., $A$. roseoalba ( $0.16 \%$ of dry plant mass) and A. collina (0.05\%). The differences in antioxidative capacity of extracts from different taxa were not statistically significant, so we can assume that specific antioxidative capacity is not bound to a specific taxon or ploidy level.

Key words: Achillea; yarrow; chamazulene; essential oils; antioxidants

Received February 02, 2021; accepted April 29, 2021.

Delo je prispelo 2. februarja 2021, sprejeto 29. aprila 2021.

Vsebnost eteričnih olj in hamazulena ter antioksidativne lastnosti izvlečkov taksonov Achillea millefolium agg. v Sloveniji

Izvleček: Raziskava je skušala razjasniti nekatere biokemijske lastnosti, pomembne za uporabo različnih vrst rmana (Achillea millefolium agg.). V raziskavo je bilo vključenih 41 populacij rmana iz Slovenije. Zajete so bile najpogostejše vrste: Achillea millefolium L., A. roseoalba Ehrend., A. collina (Wirtg.) Becker ex Rchb., A. distans Waldst. \& Kit. ex Willd., A. pannonica Scheele, A. pratensis Saukel \& R.Länger in A. nobilis L. Vsebnost eteričnih olj, določena z metodo parne destilacije, ni pokazala statistično značilnih razlik med taksoni. Vsebnost eteričnih olj je bila najmanjša pri A. collina $\left(6,50 \mathrm{ml} \mathrm{kg}^{-1}\right.$ suhe snovi), sledijo A. pannonica $\left(7,75 \mathrm{ml} \mathrm{kg}^{-1}\right)$, A. distans $\left(8,50 \mathrm{ml} \mathrm{kg}^{-1}\right)$, A. nobilis $(9,40 \mathrm{ml} \mathrm{kg}-1)$, A. pratensis $\left(9,65 \mathrm{ml} \mathrm{kg}^{-1}\right), A$. nobilis $\times$ A. millefolium $\left(12,25 \mathrm{ml} \mathrm{kg}{ }^{-1}\right)$, A. roseoalba $\left(12,75 \mathrm{ml} \mathrm{kg}^{-1}\right)$ in A. millefolium $\left(13,50 \mathrm{ml} \mathrm{kg}^{-1}\right)$. Vsebnost azulenov je bila določena $\mathrm{s}$ fotometričnimi meritvami hamazulena $\mathrm{v}$ izvlečku eteričnih olj. Hamazulen je bil prisoten le pri diploidni vrsti in eni tetraploidni vrsti, to sta $A$. roseoalba ( $0,16 \%$ suhe snovi) in A. collina $(0,05 \%)$. Razlike v antioksidativni kapaciteti izvlečkov različnih taksonov niso bile statistično različne, zato lahko sklepamo, da antioksidativne lastnosti niso vezane na določen takson ali ploidnostno stopnjo.

Ključne besede: Achillea; rman; hamazulen; eterična olja; antioksidanti

1 University of Ljubljana, Biotechnical Faculty, Agronomy Department, Ljubljana, Slovenia

2 Corresponding author, e-mail: boris.turk@bf.uni-lj.si 


\section{INTRODUCTION}

The genus Achillea (yarrow) belongs to the family Asteraceae and subfamily Anthemideae, and currently includes around 130 species (Guo et al., 2004; Ehrendorfer \& Guo, 2020). Its center of diversity is southeastern Europe (Ehrendorfer \& Guo, 2006), although its representatives are spread all over Eurasia and the North American continent. Some species, for example Achillea millefolium, were spread throughout the northern hemisphere by humans. The genus shows great ecological plasticity, with different species inhabiting dry desert areas, subalpine mountainous regions and anthropogenically modified ruderal habitats.

Different species of yarrow, used in folk medicine and phytopharmaceutical products, originate from natural populations, collected in natural habitats, or from cultivation (Vitkova et a., 2005; Edreva et al., 2017; Edreva et al., 2019). They are used as antiphlogistics, antispasmodics, hemostatics, stomachics and holagogues (Kastner et al., 1995; Ali et al., 2017). While the content of phytopharmaceutically important compounds in plants also depends on the type of habitat and climatic conditions, it is presumed to be primarily genetically conditioned, and as such limited to specific taxa. Because of that, understanding the genus systematics is not only of academic, but also of practical importance.

Among the bioactive components in yarrow, essential oils are the most important in therms of medicinal effects (Franz, 2007). The content of essential oils in dry above-ground plant parts is about 0.2-1\% (Nemeth, 2005). They include 6-19\% of chamazulene and more than 100 other components, among them monoterpenes and sesquiterpenes. The content and composition of essential oils are influenced by genetic, ontogenetic (Farhadi et al., 2020) and environmental factors (Stahl, 1952; Deufel, 1954; Radulovich et al., 2007). The differences are not only reflected in the essential oils, extracted from inflorescences, but also from the leaves (Judzentiene \& Mockute, 2005). Differences in essential oil composition are also known among taxa of different ploidy levels (Hofmann et al., 1992) and populations from different geographical provinces (Haziri et al., 2010).

The most important groups of sesquiterpene lactones found in yarrow include azulenogenic and nonazulenogenic guanolides, guanolide-endo-peroxides, 3-oxy-guanolides, eudezmanolides, longipin, and germacrenes. The basic azulenogenic guanolide in yarrow is achillicin (Kastner et al., 1995). Below-ground plant parts are characterized by their ability to synthesize and accumulate alkamides with specific olefinic and acetylenic patterns, which substitutes the synthesis of polia- cetylenic compounds, otherwise characteristic of the Anthemideae (Greger and Hofer, 1989).

Yarrow, A. millefolium s.l., is one of the first documented medicinal plants in Europe (Wagenitz, 1979). The drug Herba Milefolii is listed in the pharmacopoeias of many European countries. However, the European Pharmacopoeia (2004) explicitly mentions only Achillea millefolium L., a specific taxon from the Achillea millefolium agg. Many sources suggest there is no differentiation between individual taxa of the aggregat when collecting yarrow for use in folk medicine (Saukel \& Länger, 1992). Moreover, it is known from literature that the hexaploid taxon A. millefolium s. str. usually does not contain proazulenes at all, although its content is the ground criterion for inclusion in pharmacopoeias (Dabrowska, 1972; Oswiecimska, 1968, 1974). On the other hand, proazulenes are commonly found in di- and tetraploid species of the A. millefolium s.l. (Bugge, 1991; Adler et al., 1994). It is generally accepted that the diploid taxa $A$. asplenifolia and $A$. roseoalba do contain proazulenes, but $A$. setacea does not, despite also being diploid. Among tetraploid taxa, only A. collina produces proazulenes, but $A$. pratensis and $A$. nobilis do not. Most sources also agree that the hexaploid A. millefolium and octoploid A. pannonica do not synthesize proazulenes.

The aim of the present study was to extend the current knowledge on the phytochemical constituents in the A. millefolium agg. in Slovenia. The study included 41 yarrow populations from 41 locations all over Slovenia. The most abundant taxa were included: Achillea millefolium L., A. roseoalba Ehrend., A. collina (Wirtg.) Becker ex Rchb., A. distans Waldst. \& Kit. ex Willd., A. pannonica Scheele, A. nobilis L. and A. pratensis Saukel \& R. Länger. The goal was to estimate the content of essential oils in above-ground plant parts and test for the presence and content of proazulenes. Additionally, the study quantified antioxidative activity of extracts from collected taxa as another property, important for use in folk medicine.

\section{MATERIAL AND METHODS}

\subsection{COLLECTION AND PREPARATION OF PLANT MATERIAL}

Plant material was collected from 41 locations across Slovenia. All known basic ploidy levels of Achillea millefolium agg. were included. The taxon A. roseoalba Ehrend., which grows in humid lowland meadows, is diploid $(2 \mathrm{n}=18)$. Taxa A. collina (Wirtg.) Becker ex Rchb., A. nobilis L. and A. pratensis Saukel \& R. Länger are tetraploid $(2 \mathrm{n}=36)$, A. millefolium $\mathrm{L}$. and A. distans 
Waldst. \& Kit. ex Willd. are hexaploid $(2 \mathrm{n}=54)$ and $A$. panonica Scheele is octoploid $(2 \mathrm{n}=72)$.

Plant material was collected and prepared in the same manner for all further analyses. $500 \mathrm{~g}$ to $2000 \mathrm{~g}$ of fresh above-ground plant material was collected at each site. The quantity particularly depended on the size and abundance of the plants of each taxon in a population. In taxa where plants are large, a few dozen plants were sufficient, but where they are smaller, a few hundred were collected. At each site, plants were harvested as close to each other as possible. Due to the large amount of material collected, it was impossible to ensure that it all came from the same individual. When different morphological variants were present at the same site, only plants of the same morphological type were collected. Additional specimens for morphological measurements were collected at each site and stored in a herbarium.

The plants were cleaned of any foreign plant material, tied into small bundles, and hung in a dry, dark and airy space, where they dried at room temperature for two to three days. The upper parts of the air-dried plants with inflorescences, healthy green leaves and the attached parts of the stem were cut off, cut into approximately 10 $\mathrm{cm}$ long pieces and stored in paper bags. The dry plant material was stored at room temperature until further processing in a dark, dry room.

\subsection{EXTRACTION OF ESSENTIAL OIL AND PROA- ZULENES}

Extraction of essential oils and proazulenes was performed in accordance with the $5^{\text {th }}$ edition of the European Pharmacopoeia (2004) using $20 \mathrm{~g}$ of cut drug, a $1000 \mathrm{ml}$ round-bottomed flask and $500 \mathrm{ml}$ of a mixture of 1 volume of water and 9 volumes of ethylene glycol as the distillation liquid. $0.2 \mathrm{ml}$ of xylene in the graduated tube was added to takeup the essential oil. The destilation time was 2 hours.

\subsection{ESTIMATION OF CHAMAZULENE CONTENT IN ESSENTIAL OIL}

The content of chamazulene in the essential oil was determined photometrically in accordance with the $5^{\text {th }}$ edition of the European Pharmacopoeia (2004). After distillation, the xylene with dissolved essential oil, and with as little distillation liquid as possible, was transferred into a $50 \mathrm{ml}$ volumetric flask. Photometric measurement of absorbance was performed on a Perkin Elmer spectrophotometer, Lambda 25 UV / VIS Spectrometer at $608 \mathrm{~nm}$.

\subsection{PREPARATION OF EXTRACTS FOR ANTIOXI- DATIVE PROPERTIES ESSAY}

Plant samples, prepared in step 2.1, were shredded and mixed by hand to homogenize. Approximately $50 \mathrm{~g}$ of each sample was prepared for grinding. The instruction of the European Pharmacopoeia (2004) that the drug should not contain more than $5 \%$ of stems with a diameter exceeding $3 \mathrm{~mm}$, or more than $2 \%$ of other foreign components, was followed.

For extraction, $0.5 \mathrm{~g}$ of ground plant material was weighed and added to $5 \mathrm{ml}$ of solvent in a glass centrifuge. $80 \%$ methanol (a mixture of methanol and demineralized water in a volume ratio of $80: 20$ ) was used as solvent. Samples were stored in colorless bottles in the freezer at $-18^{\circ} \mathrm{C}$.

\subsection{MEASUREMENT OF ANTIOXIDATIVE PROP- ERTIES OF EXTRACTS}

Antioxidant activity cannot be measured directly, but the inhibitory effect of antioxidants in oxidation can, using a wide range of methods. Efficiency of oxidation can be determined by measuring any of the factors in the oxidation process - the substrate, the oxidant or the intermediate and final products of oxidation (Antolovich et al., 2002). One commonly used method is based on the use of the stable free radical diphenyl picryl hydrazyl (DPPH) (Molyneux, 2004; Yordanov et al., 1997). The results of a DPPH tests were presented by the inhibition coefficient (IC), expressing DPPH inhibition in \% and through TEAC (Trolox Equivalent Antioxidant Capacity) or antioxidant capacity in Trolox equivalents in TE units (Trolox Equivalent), i.e., in $\mathrm{mM}$ TE per $100 \mathrm{~g}$ of tested material.

\subsection{STATISTICS}

Descriptive statistics and plot production was performed using Statistica, Data Analysis Software System (StatSoft Inc., USA).

\section{RESULTS AND DISCUSSION}

\subsection{ESSENTIAL OIL AND CHAMAZULENE CON- TENT}

Measurement of essential oil content with steam distillation using the Clevenger apparatus showed no significant differences among taxa. Essential oil content 

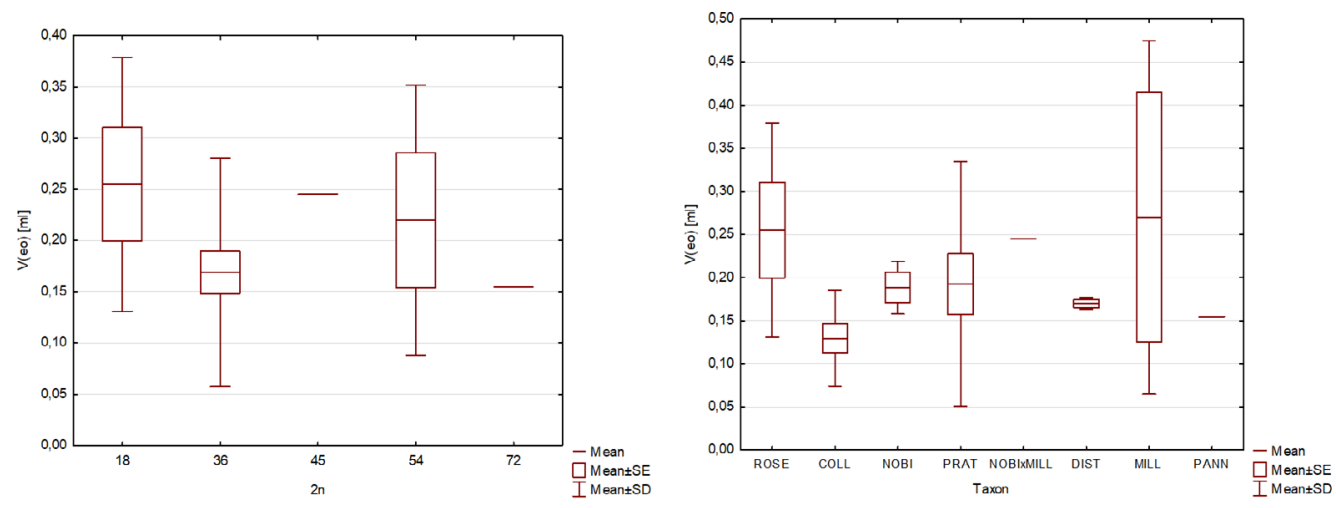

Figure 1: Essential oil volume in plant extracts by ploidy level and by taxon, expressed as ml per $20 \mathrm{~g}$ dry matter.

Table 1: Descriptive statistics and statistical significance of differences in average essential oil volume in plant extract among ploidy levels, expressed $\mathrm{ml}$ per $20 \mathrm{~g}$ of dry matter.

\begin{tabular}{|c|c|c|c|c|c|c|}
\hline Ploidy & Average $[\mathrm{ml}]$ & Sig. & Min. [ml] & Max. [ml] & $\mathrm{SD}[\mathrm{ml}]$ & $\mathrm{SE}[\mathrm{ml}]$ \\
\hline $2 \mathrm{n}=72$ & 0.155 & $\mathrm{a}$ & 0.155 & 0.155 & & \\
\hline $2 n=36$ & 0.169 & $\mathrm{a}$ & 0.055 & 0.555 & 0.112 & 0.020 \\
\hline $2 n=54$ & 0.220 & $\mathrm{a}$ & 0.125 & 0.415 & 0.132 & 0.066 \\
\hline $2 \mathrm{n}=45$ & 0.245 & a & 0.245 & 0.245 & & \\
\hline 2n 18 & 0.255 & a & 0.125 & 0.445 & 0.124 & 0.055 \\
\hline
\end{tabular}

Note: same letters in column Sig. denote cases with no statistically significant difference (Duncan test, $\mathrm{p} \leq 0.05$ )

Table 2: Descriptive statistics and statistical significance of differences in average essential oil volume in plant extract among taxa, expressed in $\mathrm{ml}$ per $20 \mathrm{~g}$ of dry matter.

\begin{tabular}{|c|c|c|c|c|c|c|}
\hline Taxon & Average $[\mathrm{ml}]$ & Sig. & Min. [ml] & Max. [ml] & $\mathrm{SD}[\mathrm{ml}]$ & $\mathrm{SE}[\mathrm{ml}]$ \\
\hline COLL & 0.130 & $\mathrm{a}$ & 0.075 & 0.275 & 0.056 & 0.017 \\
\hline PANN & 0.155 & a & 0.155 & 0.155 & & \\
\hline DIST & 0.170 & a & 0.165 & 0.175 & 0.007 & 0.005 \\
\hline NOBI & 0.188 & $\mathrm{a}$ & 0.155 & 0.215 & 0.031 & 0.018 \\
\hline PRAT & 0.193 & a & 0.055 & 0.555 & 0.142 & 0.035 \\
\hline NOBIxMILL & 0.245 & a & 0.245 & 0.245 & & \\
\hline ROSE & 0.255 & $\mathrm{a}$ & 0.125 & 0.445 & 0.124 & 0.055 \\
\hline MILL & 0.270 & a & 0.125 & 0.415 & 0.205 & 0.145 \\
\hline
\end{tabular}

Note: same letters in column Sig. denote cases with no statistically significant difference (Duncan test, $p \leq 0.05$ ) 
was the lowest in A. collina, with $6.50 \mathrm{ml}$ per $\mathrm{kg}$ of dry matter (s. d. $2.80 \mathrm{ml}$ ), followed by $A$. pannonica with $7.75 \mathrm{ml} \mathrm{kg}^{-1}$, A. distans with $8.50 \mathrm{ml} \mathrm{kg}^{-1}$ (s. d. $0.35 \mathrm{ml}$ ), A. nobilis with $9.40 \mathrm{ml} \mathrm{kg}^{-1}$ (s. d. $1.55 \mathrm{ml}$ ), A. pratensis with $9.65 \mathrm{ml} \mathrm{kg}^{-1}$ (s. d. $7.1 \mathrm{ml}$ ), A. nobilis $\times$ A. millefolium with $12.25 \mathrm{ml} \mathrm{kg}^{-1}$ and $A$. roseoalba with $12.75 \mathrm{ml} \mathrm{kg}^{-1}$ (s. d. $6.20 \mathrm{ml}$ ). The highest essential oil content was estimated

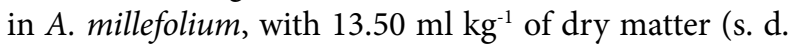
$10.25 \mathrm{ml}$ ).

Total essential oil content was consistent with existing data (Gharibi et al., 2015), while maximum differences between species were just approximately two-fold, much less than some other studies report. Orav et al. (2006) found nine-fold variance in essential oil yield in yarrow samples, and even twenty-seven-fold differences have been reported from Achillea samples from Iran (Rahimmalek et al., 2009). Consistent essential oil content in our study may be explained by the fact that the present study only included species from the $A$. millefolium agg., whereas other studies also took into account some taxonomically less related species. In addition, care was taken to only use the inflorescences and uppermost leaves, with as little stems as possible, since some studies showed large differences in essential oil content between the two plant parts, e. g. $0.65 \%(\mathrm{v} / \mathrm{w})$ in flowers and $0.0125 \%(\mathrm{v} / \mathrm{w})$ in stems (Bocevska \& Sovova, 2007). The oil yield in all our samples conformed to the European pharmacopoeia 5.0 (2004) standard which is not less than $0.2 \%$.

Proazulenes, measured through chamazulene, were only present in A. roseoalba and A. collina. This is, to some extent, consistent with existing literature, suggesting only diploid and tetraploid taxa are proazulenogenic (Gherase et al., 2003; Nemeth et al., 2007; Konakchiev et al., 2005), although some researchers claim that azulenes can be found in all ploidy levels, albeit in different proportions (Kindlovits et al., 2012). However, the data on proazulene presence is quite contradictory (Nemeth, 2005). Even so, in our research, only the diploid A. roseoalba consistently contained chamazulene (with population differences ranging from $2.648 \%$ of dry mass to $0.351 \%$ of dry mass). No difference in chamazulene content was detected between white-flowering and pinkflowering diploid individuals from the same population. In contrast, chamazulene content in the tetraploid A. collina was less consistent, and not significantly different from other taxa, except $A$. roseoalba. Chamazulene content found in different populations ranged from $0.171 \%$ of dry mass to $0.003 \%$ of dry mass.
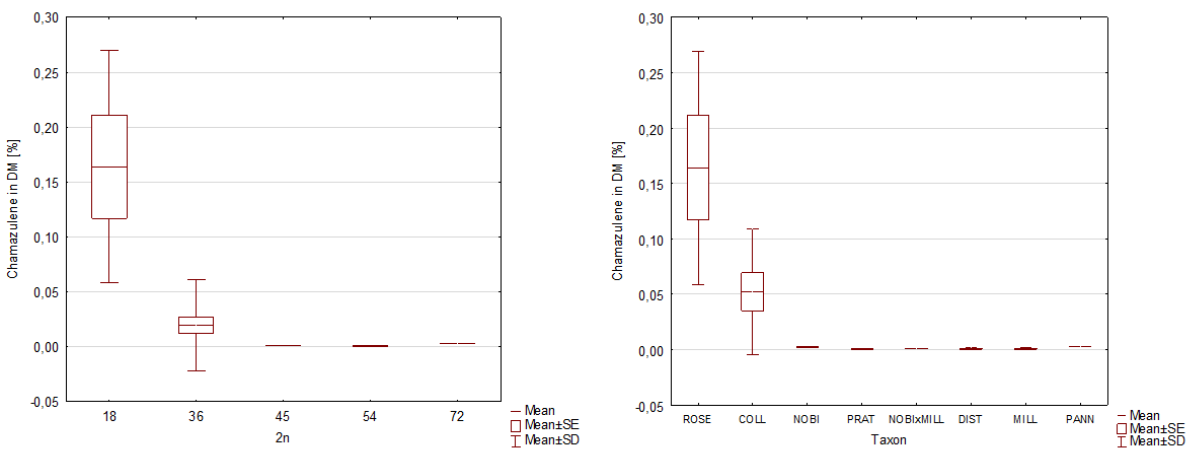

Figure 2: Chamazulene content in \% of dry matter by ploidy level and by taxon.

Table 3: Descriptive statistics and statistical significance of differences in average chamazulene content in \% of dry matter among ploidy levels.

\begin{tabular}{ccccccc}
\hline Ploidy & Average [\%] & Sig. & Min. [\%] & Max. [\%] & SD [\%] & SE [\%] \\
\hline $2 \mathrm{n}=54$ & 0.001 & $\mathrm{a}$ & 0.0002 & 0.0014 & 0.0006 & 0.0003 \\
$2 \mathrm{n}=45$ & 0.001 & $\mathrm{a}$ & 0.0010 & 0.0010 & & \\
$2 \mathrm{n}=72$ & 0.003 & $\mathrm{a}$ & 0.0028 & 0.0028 & & 0.0076 \\
$2 \mathrm{n}=36$ & 0.020 & $\mathrm{a}$ & 0.0000 & 0.1706 & 0.0418 & 0.0472 \\
$2 \mathrm{n}=18$ & 0.164 & $\mathrm{~b}$ & 0.0357 & 0.2742 & 0.1055 & 0.055 \\
\hline
\end{tabular}

Note: same letters in column Sig. denote cases with no statistically significant difference (Duncan test, $\mathrm{p} \leq 0.05$ ) 
Table 4: Descriptive statistics and statistical significance of differences in average chamazulene content in \% of dry matter among taxa.

\begin{tabular}{ccccccc}
\hline Taxon & Average [\%] & Sig. & Min. [\%] & Max. [\%] & SD [\%] & SE [\%] \\
\hline PRAT & 0.001 & a & 0.000 & 0.002 & 0.001 & 0.000 \\
DIST & 0.001 & a & 0.000 & 0.001 & 0.001 & 0.001 \\
MILL & 0.001 & a & 0.000 & 0.001 & 0.001 & 0.000 \\
NOBIxMILL & 0.001 & a & 0.001 & 0.001 & & 0.000 \\
NOBI & 0.002 & a & 0.002 & 0.003 & 0.001 & 0.017 \\
PANN & 0.003 & a & 0.003 & 0.003 & & 0.057 \\
COLL & 0.052 & a & 0.003 & 0.171 & 0.106 & 0.047 \\
ROSE & 0.164 & $\mathrm{~b}$ & 0.036 & 0.274 & & \\
\hline
\end{tabular}

Note: same letters in column Sig. denote cases with no statistically significant difference (Duncan test, $\mathrm{p} \leq 0.05$ )
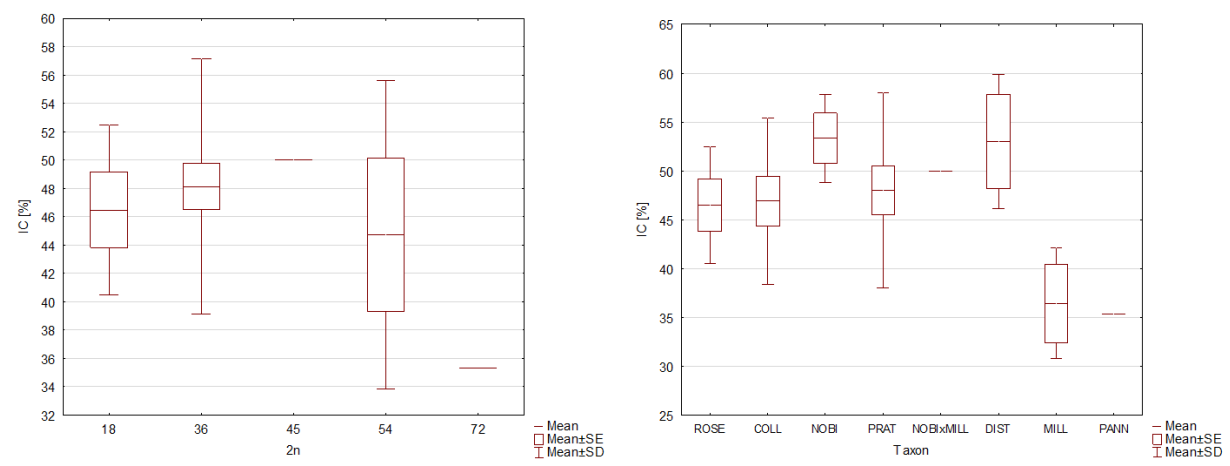

Figure 3: DPPH inhibition coefficient (IC) in \% by ploidy level and by taxon.

Table 5: Descriptive statistics and statistical significance of differences in average DPPH inhibition coefficients (IC) in \% among ploidy levels.

\begin{tabular}{ccccccc}
\hline Ploidy & Average [\%] & Sig. & Min. [\%] & Max. [\%] & SD [\%] & SE [\%] \\
$2 \mathrm{n}=72$ & 35.34 & $\mathrm{a}$ & 35.34 & 35.34 & & \\
$2 \mathrm{n}=54$ & 44.72 & $\mathrm{a}$ & 32.43 & 57.86 & 10.86 & 5.43 \\
$2 \mathrm{n}=18$ & 46.49 & $\mathrm{a}$ & 40.94 & 55.26 & 5.99 & 2.68 \\
$2 \mathrm{n}=36$ & 48.14 & $\mathrm{a}$ & 25.87 & 65.29 & 9.02 & 1.65 \\
$2 \mathrm{n}=45$ & 50.00 & $\mathrm{a}$ & 50.00 & 50.00 & & \\
\hline
\end{tabular}

Note: same letters in column Sig. denote cases with no statistically significant difference (Duncan test, $\mathrm{p} \leq 0.05$ ) 
Table 6: Descriptive statistics and statistical significance of differences in average DPPH inhibition coefficients (IC) in \% among taxa.

\begin{tabular}{|c|c|c|c|c|c|c|}
\hline Taxon & Average [\%] & Sig. & Min. [\%] & Max. [\%] & $\mathrm{SD}[\%]$ & SE [\%] \\
\hline PANN & 35.34 & $\mathrm{a}$ & 35.34 & 35.34 & & \\
\hline MILL & 36.43 & a & 32.43 & 40.44 & 5.66 & 4.00 \\
\hline ROSE & 46.49 & a & 40.94 & 55.26 & 5.99 & 2.68 \\
\hline COLL & 46.91 & a & 34.83 & 65.29 & 8.52 & 2.57 \\
\hline PRAT & 48.02 & a & 25.87 & 61.85 & 9.98 & 2.49 \\
\hline $\begin{array}{c}\text { NOBI } x \\
\text { MILL }\end{array}$ & 50.00 & a & 50.00 & 50.00 & & \\
\hline DIST & 53.02 & $\mathrm{a}$ & 48.17 & 57.86 & 6.86 & 4.85 \\
\hline NOBI & 53.34 & $\mathrm{a}$ & 49.92 & 58.43 & 4.49 & 2.59 \\
\hline
\end{tabular}

Note: same letters in column Sig. denote cases with no statistically significant difference (Duncan test, $\mathrm{p} \leq 0.05$ )

Table 7: Descriptive statistics and statistical significance of differences in Trolox Equivalent Antioxidant Capacity (TEAC) in $\mu \mathrm{M}$ TE per $100 \mathrm{~g}$ of dry plant matter among ploidy levels.

\begin{tabular}{ccccccc}
\hline Ploidy & Average $[\mu \mathrm{M}]$ & Sig. & Min. $[\mu \mathrm{M}]$ & Max. $[\mu \mathrm{M}]$ & SD $[\mu \mathrm{M}]$ & SE $[\mu \mathrm{M}]$ \\
\hline $2 \mathrm{n}=72$ & 42.54 & $\mathrm{a}$ & 42.54 & 42.54 & & \\
$2 \mathrm{n}=54$ & 54.65 & $\mathrm{a}$ & 38.78 & 71.60 & 14.02 & 7.01 \\
$2 \mathrm{n}=18$ & 56.93 & $\mathrm{a}$ & 49.77 & 68.25 & 7.73 & 3.46 \\
$2 \mathrm{n}=36$ & 59.06 & $\mathrm{a}$ & 30.32 & 81.17 & 11.63 & 2.12 \\
$2 \mathrm{n}=45$ & 61.46 & $\mathrm{a}$ & 61.46 & 61.46 & & \\
\hline
\end{tabular}

Note: same letters in column Sig. denote cases with no statistically significant difference (Duncan test, $\mathrm{p} \leq 0.05$ )

Table 8: Descriptive statistics and statistical significance of differences in Trolox equivalent antioxidant capacity (TEAC) in $\mu \mathrm{M}$ TE per $100 \mathrm{~g}$ of dry plant matter among taxa.

\begin{tabular}{ccccccc}
\hline Taxon & Average $[\mu \mathrm{M}]$ & Sig. & Min. $[\mu \mathrm{M}]$ & Max. $[\mu \mathrm{M}]$ & SD $[\mu \mathrm{M}]$ & SE $[\mu \mathrm{M}]$ \\
\hline PANN & 42.54 & $\mathrm{a}$ & 42.54 & 42.54 & & 7.31 \\
MILL & 43.95 & $\mathrm{a}$ & 38.78 & 49.12 & 6.17 \\
ROSE & 56.93 & $\mathrm{a}$ & 49.77 & 68.25 & 7.73 & 3.46 \\
COLL & 57.47 & $\mathrm{a}$ & 41.88 & 81.17 & 11.00 & 3.32 \\
PRAT & 58.89 & $\mathrm{a}$ & 30.32 & 76.74 & 12.87 & 3.22 \\
NOBIxMILL & 61.46 & $\mathrm{a}$ & 61.46 & 61.46 & & \\
DIST & 65.34 & $\mathrm{a}$ & 59.09 & 71.60 & 8.84 & 6.25 \\
NOBI & 65.76 & $\mathrm{a}$ & 61.35 & 72.32 & 5.79 & 3.35 \\
\hline
\end{tabular}

Note: same letters in column Sig. denote cases with no statistically significant difference (Duncan test, $\mathrm{p} \leq 0.05$ ) 


\subsection{ANTIOXIDATIVE ACTIVITY OF THE EX- TRACTS}

The differences in antioxidative capacity were not statistically significant among extracts from plants with different ploidy levels and of different taxa. The results showed a large range of antioxidant efficacy in the samples. The DPPH radical inhibition coefficient (IC) ranged from $25.87 \%$ in a population of $A$. pratensis, to $65.29 \%$ in a population of $A$. collina. The highest detected value of Trolox equivalent antioxidative capacity (TEAC) was more than twice as high as the lowest. The values ranged from $81.17 \mu \mathrm{M}$ in an A. collina population to $30.32 \mu \mathrm{M}$ in an A. pratensis population (both tetraploid). The distribution of IC values was relatively continuous, with no obvious groupings. Based on the results, it can be assumed that specific antioxidative capacity is not associated with a specific taxon or ploidy level. Since the amount of antioxidants, as well as proazulenes, as shown by Stahl (1952), can be affected by environmental conditions and stress, or can even be related to the plant communities in which yarrow grows (Michler \& Arnold, 1999; Radušiene \& Gudaityte, 2005), it might be worth exploring the correlation between environmental conditions, in which the sampled plants grew, and their antioxidative activity.

\section{CONCLUSIONS}

Due to the importance of yarrow from the Achillea millefolium agg. in folk medicine and phytopharmaceuticals on one side, and great genotypical and phenotypical plasticity of the aggregate on the other, distinguishing among individual taxa is crucial. It is known, for instance, that taxa with different ploidy levels exhibit different abilities for proazulenic compound synthesis. The influence of environmental conditions and stress at the growing site is also important (Gudaityte, 2008), although some authors did not find any correlation (Nemeth, 2007). No such evaluation of the most abundant taxa from the $A$. millefolium agg. has so far been done in Slovenia.

The present study showed that the ability of proazulenic compound synthesis in Slovenian taxa greatly corresponds to the general patterns. The highest chamazulene content was found in the only diploid taxon included in the study, A. roseoalba. Although the differences in the content among individual populations were quite large, ranging from $2.65 \%$ to $0.35 \%$ of dry plant matter, it was the only taxon with consistent chamazulene presence. The only other taxon, where chamazulene was found, was the tetraploid A. collina. Here, chamazulene content never exceeded $0.17 \%$ of dry plant matter. We can conclude that only $A$. roseoalba, occurring predominantly in wet meadows and slightly acidic fens (Dunkel et. al., 2011; Saukel, 2008), is worth being collected as a source of chamazulene.

There was a lot of variability in essential oil content among samples. No significant differences among taxa or ploidy levels could be found, perhaps also due to the small number of samples. Still, it appears that when picking yarrow for its essential oils, all taxa are similarly suitable for collection. The composition of essential oils, which was not tested here, however, most probably differs among taxa (Yener et al., 2020).

Similar conclusions were obtained from the assay of antioxidative properties. Antioxidative activity of the extracts showed no significant differences among taxa, but variability within taxa was large. One can speculate that antioxidative capacity is not determined only genetically, but largely depends on environmental and stress conditions.

\section{REFERENCES}

Adler, W., Osvald, K., Fischer, R. (1994). Exkursionsflora von Österreich. Bestimmungsbuch für alle in Österreich wildwachsenden sowie die wichstigsten kultivierten Gefäßpflanzen (Farnpflanzen und Samenpflanzen) mit Angaben über ihre Ökologie und Verbreitung. Stuttgart und Wien, Verlag Eugen Ulmer. 1180pp.

Ali, S. I., Gopalakrishnan, B., \& Venkatesalu, V. (2017). Pharmacognosy, phytochemistry and pharmacological properties of Achillea millefolium L.: a review. Phytotherapy Research, 31(8), 1140-1161. https://doi.org/10.1002/ptr.5840

Antolovich, M., Prenzler, P. D., Patsalides, E., McDonald, S., \& Robards, K. (2002). Methods for testing antioxidant activity. Analyst, 127(1), 183-198. https://doi.org/10.1039/ b009171p

Bocevska, M., \& Sovova, H. (2007). Supercritical CO2 extraction of essential oil from yarrow. The Journal of Supercritical Fluids, 40(3), 360-367. https://doi.org/10.1016/j.supflu.2006.07.014

Bugge, G. (1991). Untersuchungen der Sippen des Achilleamillefolium-Komplexes auf Azulengehalt und Ploidiegrad. Angewandte Botanik, 65(5-6), 331-339.

Dabrowska, J. (1972). Obserwacje rozmieszczenia azulenowych i bezazulenowych form Achillea L. na Śląsku, na tle danych o rozmieszczeniu taksonów rodzaju Achillea L. na tym obszarze. Herba Polonica Journal, 18, 40-69.

Deufel, J. (1954). Der Azulengehalt tetraploider Schafgarben. Pharmazie, 9(9), 756.

Dunkel, F. G., Gregor, T., \& Meierott, L. (2011). Achillea roseoalba-a long ignored relict in Germany. Feddes Repertorium, 122(3-4), 268-274. https://doi.org/10.1002/fedr.201000005

Edreva, A., Vitkova, A., Dagnon, S., Konakchiev, A., Gesheva, E., \& Bojilov, D. (2017). Field-cultivated medicinal plants of Achillea millefolium: a source of bioactive compounds. Genetics and Plant Physiology, 7(1-2), 22-33.

Edreva, A., Vitkova, A., \& Gesheva, E. (2019). Field-cultivated 
plants from Achillea millefolium: total flavonoid content, antiradical and antioxidant activities in stems and leaves, and ratio of plant parts. Genetics and Plant Physiology, 9(12), 03-10.

Ehrendorfer, F., \& Guo, Y. P. (2006). Multidisciplinary studies on Achillea sensu lato (Compositae-Anthemideae): new data on systematics and phylogeography. Willdenowia, 6987. https://doi.org/10.3372/wi.36.36105

European pharmacopoeia 5.0. (2004). Strassbourg, Council of Europe, 2416pp.

Farhadi, N., Babaei, K., Farsaraei, S., Moghaddam, M., \& Pirbalouti, A. G. (2020). Changes in essential oil compositions, total phenol, flavonoids and antioxidant capacity of Achillea millefolium at different growth stages. Industrial Crops and Products, 152, 112570. https://doi.org/10.1016/j.indcrop.2020.112570

Franz, C., Bauer, R., Carle, R., Tedesco, D., Tubaro, A., \& ZitterlEglseer, K. (2007). Study on the assessment of plants/herbs, plant/herb extracts and their naturally or synthetically produced components as 'additives' for use in animal production. EFSA Supporting Publications, 4(4), 070828. https:// doi.org/10.2903/sp.efsa.2007.ZN-001

Gharibi, S., Tabatabaei, B. E. S., \& Saeidi, G. (2015). Comparison of essential oil composition, flavonoid content and antioxidant activity in eight Achillea species. Journal of Essential Oil Bearing Plants, 18(6), 1382-1394. https://doi.org/10 .1080/0972060X.2014.981600

Gherase, F., Spac, A., Dorneanu, V., Stănescu, U., \& Grigorescu, E. (2003). Pharmacognostic research of some species of Achillea. Note 1. Volatile oils analysis. Revista medico-chirurgicala a Societatii de Medici si Naturalisti din Iasi, 107(1), 188-191.

Greger, H., \& Hofer, O. (1989). Polyenoic acid piperideides and other alkamides from Achillea millefolium. Phytochemistry, 28(9), 2363-2368. https://doi.org/10.1016/S00319422(00)97985-8

Gudaityte, O. (2008). Evaluation of yarrow (Achillea L.) intraspecific diversity and selection of samples by phytochemical properties and morphological characters. Summary of doctoral dissertation, Vilnius, 5-22.

Guo, Y. P., Ehrendorfer, F., \& Samuel, R. (2004). Phylogeny and systematics of Achillea (AsteraceaeAnthemideae) inferred from nrITS and plastid trnLF DNA sequences. Taxon, 53(3), 657-672. https://doi.org/10.2307/4135441

Haziri, A. I., Aliaga, N., Ismaili, M., Govori-Odai, S., Leci, O., Faiku, F., ... \& Haziri, I. (2010). Secondary metabolites in essential oil of Achillea millefolium (L.) growing wild in east part of Kosova. American Journal of Biochemistry and Biotechnology, 6(1), 32-34. https://doi.org/10.3844/ajbbsp.2010.32.34

Hofmann, L., Fritz, D., Nitz, S., Kollmannsberger, H., \& Drawert, F. (1992). Essential oil composition of three polyploids in the Achillea millefolium 'complex'. Phytochemistry, 31(2), 537-542. https://doi.org/10.1016/0031-9422(92)90034-N

Judzentiene, A., \& Mockute, D. (2005). Composition of inflorescence and leaf essential oils of Achillea millefolium L. with white, pink and deep pink flowers growing wild in Vilnius (Eastern Lithuania). Journal of Essential Oil Research,
17(6), 664-667. https://doi.org/10.1080/10412905.2005.969 9027

Kastner, U., Glasl, S., Jurenitch, J. (1995). Achillea millefolium - ein Gallentherapeutikum? Gedanken über den aktuellen Einsatz einer alten Arzneipflanze. Zeitschrift für Phytotherapie, 16, 34-36.

Kindlovits, S., \& Németh, É. (2012). Sources of variability of yarrow (Achillea spp.) essential oil. Acta alimentaria, 41(Supplement-1), 92-103. https://doi.org/10.1556/AAlim.41.2012.Suppl.9

Konakchiev, A., Mikhova, B., Todorova, M., Najdenski, H., Tzvetkova, I., Vitkova, A., \& Duddeck, H. (2005). Composition of the essential oil of Achillea asplenifolia Vent. from Bulgaria. Journal of Essential Oil Bearing Plants, 8(3), 318323. https://doi.org/10.1080/0972060X.2005.10643459

Michler, B., \& Arnold, C. G. (1999). Predicting presence of proazulenes in the Achillea millefolium. Folia Geobotanica, 34(1), 143-161. https://doi.org/10.1007/BF02803081

Molyneux, P. (2004). The use of the stable free radical diphenylpicrylhydrazyl (DPPH) for estimating antioxidant activity. Songklanakarin Journa of Science and Technoogyl, 26(2), 211-219.

Nemeth, E. (2005). Essential oil composition of species in the genus Achillea. Journal of Essential Oil Research, 17(5), 501512. https://doi.org/10.1080/10412905.2005.9698978

Nemeth, E., Bernáth, J., Sárosi, S., \& Rajhárt, P. (2007). Hazai cickafark (Achillea spp.) populációk drogminőségének vizsgálata. Evaluation of the quality of drugs from Hungarian yarrow populations.) Kertgazdaság-Horticulture, 39(1), 53 59.

Orav, A., Arak, E., \& Raal, A. (2006). Phytochemical analysis of the essential oil of Achillea millefolium L. from various European Countries. Natural Product Research, 20(12), 10821088. https://doi.org/10.1080/14786410500510849

Oswiecimska, M. (1968). Achillea collina Becker-ein proazulenhaltiges Taxon von Achillea millefolium L. s. 1. Planta Medica, 16(2), 201-207. https://doi.org/10.1055/s-0028-1099900

Oswiecimska, M. (1974). Korrelation zwischen chromosomenzahl und prochamazulenen in Achillea von Osteuropa. Planta Medica, 25(04), 389-395. https://doi. org/10.1055/s-0028-1097960

Radulovic, N., Zlatković, B., Palic, R., \& Stojanovic, G. (2007). Chemotaxonomic significance of the Balkan Achillea volatiles. Natural Product Communications, 2(4), 1934578X0700200417. https://doi. org/10.1177/1934578X0700200417

Radušiene, J., \& Gudaityte, O. (2005). Distribution of proazulenes in Achillea millefolium sl wild populations in relation to phytosociological dependence and morphological characters. Plant Genetic Resources, 3(2), 136-143. https://doi. org/10.1079/PGR200568

Rahimmalek, M., Tabatabaei, B. E. S., Etemadi, N., Goli, S. A. H., Arzani, A., \& Zeinali, H. (2009). Essential oil variation among and within six Achillea species transferred from different ecological regions in Iran to the field conditions. Industrial Crops and Products, 29(2-3), 348-355. https://doi. org/10.1016/j.indcrop.2008.07.001

Saukel, J. (2008). Achillea millefolium agg. In: Fischer, M. A., Oswald, K., \& Wagner, W. (2008). Exkursionsflora für Öster- 
reich, Liechtenstein und Südtirol. 3., verb. Aufl. Biologiezentrum d. Oberösterr. Landesmuseen, Linz. 1392pp.

Saukel, J., Länger, R. (1992). Die Achillea millefolium - Gruppe (Asteraceae) in Mitteleuropa, 1. Problemstellung, Merkmalserhebung und Untersuchungsmaterial. Phyton (Horn, Austria), 31(2), 185-207.

Stahl, E. (1952). Ist der Proazulengehalt der Schafgarbe (Achillea millefolium L.) genetisch oder umweltbedingt?. Pharmazie, 7, 863-868.

Vitkova, A., Anchev, M., Goranova, V., Todorova, M., \& Konakchiev, A. (2005). Achillea millefolium (Asteraceae) in Bulgaria. Farmatsiya, 52, 60-63.
Wagenitz, G. (1979). Compositae I: Allgemeiner Teil, Eupatorium-Achillea. Illustrierte Flora von Mitteleuropa, 6, 133-136.

Yener, I., Yilmaz, M. A., Olmez, O. T., Akdeniz, M., Tekin, F., Hasimi, N., ... \& Ertas, A. (2020). A Detailed Biological and Chemical Investigation of Sixteen Achillea Species' Essential Oils via Chemometric Approach. Chemistry \& Biodiversity, 17(3), e1900484. https://doi.org/10.1002/cbdv.201900484

Yordanov, N. D., \& Christova, A. G. (1997). Quantitative spectrophotometric and EPR-determination of 1, 1-diphenyl2-picryl-hydrazyl (DPPH). Fresenius' Journal of Analytical Chemistry, 358(5), 610-613. https://doi.org/10.1007/ s002160050478 